\title{
MULTIDRUG-RESISTANT BACTERIAL INFECTIONS OF THE LIBYAN CIVIL WAR VICTIMS: WHAT DID WE LEARN?
}

\author{
LIBYA IÇ SAVAŞ YARALANMALARININ ÇOKLU DIRENÇLI BAKTERILERLE OLAN \\ INFEKSIYYONLARI: NE ÖĞRENDIK?
}

\author{
Zehra Çağla KARAKOÇ ${ }^{1}$ (D), Taner BEKMEZCi ${ }^{2}$, Ahmet BAŞEL ${ }^{3}$ (D) Binnur PINARBAŞI ŞiMŞEK ${ }^{4}$ (D) \\ Istinye University Faculty of Medicine, ${ }^{1}$ Department of Infectious Diseases and Clinical Microbiology, ${ }^{3}$ Department of Anesthesiology and \\ Reanimation, ${ }^{4}$ Department of Gastroenterohepatology, Istanbul, Turkey \\ ${ }^{2}$ Liv Hospital, Clinic of Orthopedics and Traumatology, Istanbul, Turkey
}

ORCID IDs of the authors: Z.Ç.K. 0000-0002-1618-740X; T.B. 0000-0003-3962-2491; A.B. 0000-0002-9681-074X;

B.P.Ş. 0000-0003-3412-3976

Cite this article as: Karakoc ZC, Bekmezci T, Basel A, Pinarbasi Simsek B. Multidrug-resistant bacterial infections of the Libyan civil war victims: what did we learn? J Ist Faculty Med 2020;83(3):267-74. doi: 10.26650/IUITFD.2019.0075

\begin{abstract}
Objective: Complicated by nosocomial infections and wide spectrum antibiotherapy, combat related injuries (CRI) are associated with resistant gram-negative microorganisms, especially at the later stage. The aim of this study is to retrospectively investigate demographic, clinical and microbiologic characteristics of $45 \mathrm{CRI}$ patients transferred from Libya and hospitalized in a private clinic.
\end{abstract}

Material and Method: Surveillance cultures (nasal, rectal, wound swabs, trakeal aspirates, urine and blood cultures) were obtained and isolated bacteria and their antibiotic susceptibility were identified using VITEK ${ }^{\circledast} 2$ system (bioMérieux, Marcy I'Etoile, France).

Results: The median age of 45 patients (44 [97.8\%] male) was $30.7 \pm 12.9$ years. The majority of the injuries were due to firearms (66.7\%) and 22 (48.9\%) patients were injured on the lower extremities. Open bone fractures were present in 30 (66.6\%) patients. Primary wound site infection was present in 28 (62.2\%) patients. Surveillance cultures revealed 40 microorganisms from the samples of 29 patients, which were gram-negative rods in 22 (55\%), gram-positive cocci in 17 (42.5\%) and fungus in 1 (2.5\%) patients). Of the 40 isolated microorganisms, 13 (32.5\%) were non-resistant, 10 (22.2\%) were MDR, and 13 (28.9\%) were XDR. None of the patients died in the study period.

Conclusion: Despite the limited number of cases, this study presents the characteristics of the Libyan combat victims treated by a multidisciplinary team at a single center. Surveillance cultures revealed many victims to be infected or colonised by MDR/ XDR bacteria. Early surgical wound debridement, early initiation

\section{ÖZET}

Amaç: Savaş yaralanmalarında gelişen yara yeri enfeksiyonlarında; geç dönemde nozokomiyal bulaş ve empirik uygulanan geniş spektrumlu antibiyoterapiler nedeniyle dirençli gram negatif mikroorganizmalar sorumlu etken olarak karşımıza çıkmaktadır. Çalışmamızda Libya'dan hastanemize transfer edilen 45 sivil savaş yaralanmalı olgunun demografik, klinik ve mikrobiyolojik özelliklerinin retrospektif olarak araştırılması amaçlanmıştır.

Gereç ve Yöntem: Dirençli bakteri kolonizasyonlarını saptamak amacı ile sürveyans kültürleri (burun, rektal, idrar, yara, endotrakeal aspirat, kan kültürü) alınmış ve üreyen mikroorganizmalar ve antibiyotik duyarlılıkları VITEK ${ }^{\circledast} 2$ (bioMérieux, Marcy l'Etoile, Fransa) otomatize sistemi ile tanımlanmıştır.

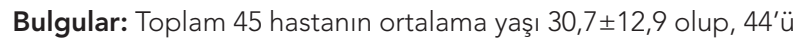
$(\% 97,8)$ erkekti. Yaralanmaların çoğunluğu $(\% 66,7)$ ateşli silah yaralanmasıydı ve 22 'si $(\% 48,9)$ alt ekstremitedeydi. Hastaların 30 'unda (\%66) açık kemik kırı̆ı̆ı ve $28^{\prime}$ inde $(\% 62,2)$ primer yara yeri infeksiyonu vardı. Surveyans kültürlerinde 29 hastada 40 mikroorganizma üremesi saptandı ve bunların 22'si (\%55) gram-negatif çomak, 17 'si $(\% 42,5)$ gram-pozitif kok ve 1'i $(\% 2,5)$ mantardı. İzole edilen mikroorganizmaların 13'ünde $(\% 32,5)$ direnç saptanmazken; 10'unda $(\% 22,2)$ çoklu ilaç direnci (ÇiD), 13 'ünde $(\% 28,9)$ ise genişletilmiş ilaç direnci (GID) saptandı. Hiçbir hastada mortalite gelişmedi.

Sonuç: Çalışmamızda; savaş yaralanması nedeni ile kabul edilen olgulara ait tek merkez deneyimimiz paylaşıldı. Çoğu hastanın ÇiD/GiD bakterilerle infekte veya kolonize oldukları görüldü. Olgularımızın genç ve komorbiditelerinin bulunmaması, tedavide

Corresponding author/iletişim kurulacak yazar: ckarakoc@gmail.com

Submitted/Başvuru: 08.09.2019• Revision Requested/Revizyon Talebi: 20.01.2020 •

Last Revision Received/Son Revizyon: 20.01.2020 • Accepted/Kabul: 30.01.2020 • Published Online/Online Yayın: 04.05.2020

(C)Telif Hakkı $2020 \mathrm{~J}$ Ist Faculty Med - Makale metnine jmed.istanbul.edu.tr web sayfasından ulaşılabilir.

(C) Copyright 2020 by J Ist Faculty Med - Available online at jmed.istanbul.edu.tr 
of antibiotic therapy in the proper dose and spectrum, and obtaining wound site cultures whenever necessary may help to provide more favorable outcomes in CRI victims.

Keywords: Combat, extensively drug resistant, Libyan, multidrug-resistant uzun süreli antibiyoterapilerin kullanımına olanak sağlarken, sık yara debritmanı ve negatif basınçlı yara kapama tedavisinin de iyi sonuçlarımıza katkıda bulunduğu düşünüldü. Savaş yaralanmalarında; erken cerrahi debritman, uygun doz ve spektrumda antibiyotik uygulamaları, gerekli durumlarda yara yeri ve surveyans kültürlerinin alımı ile sonuçlar yüz güldürücü olabilmektedir.

Anahtar Kelimeler: Çoklu ilaç direnci, Libya, savaş

\section{INTRODUCTION}

Combat related injuries (CRI) are associated with more severe impact, resulting in multiple sites of trauma and contamination with more bacteria, compared to injuries encountered in civilian life. Performing rapid resuscitation and proper surgical debridement to the injured patient and admitting the patient to a center specialized in trauma care is essential in CRI. Most common sites of injury in CRI are the extremities, as they have consistently been historically. Even though the frequency of upper and lower extremity injuries are similar, lower extremity injuries are prone to be more severe and are associated with infections especially when vascular structures are involved (1).

One of the major complications of $\mathrm{CRI}$ is the infection of the injury site, which is the second most common cause of mortality following hemorrhagic shock in this patient group. While the early infections of the wound site are generally caused by members of the dermal flora (gram-positive cocci, coagulase negative staphylococci and streptococci), later infections are associated with resistant gram-negative microorganisms (e.g., Acinetobacter baumannii-calcaoceticus, Pseudomonas aeruginosa and Enterobacteriaceae) as a consequence of nosocomial infections and wide spectrum antibiotherapy (2).

The devastation of war extends far beyond the fronts lines and may hamper the advanced, or even the basic healthcare facilities, at the conflict zones. The international community may intervene in these situations to transfer the wounded individuals to nearby countries for treatment and follow up. Contracts secured between Libya and Turkey in 2012 enabled the transportation of many victims of the Libyan civil war to state or private hospitals in Turkey for treatment and follow up after their primary care and stabilization in their home country. The aim of this study is to retrospectively investigate the demographic, clinical and microbiological characteristics of the Libyan CRI victims hospitalized in a private clinic in Turkey.

\section{MATERIAL AND METHOD}

A total of 97 civilian CRI victims transferred from Libya and admitted to a private hospital with a 160 bed capacity between November 2013 and October 2015 were included in this retrospective study. Patients discharged within 48 hours of admittance $(n=38)$, those with surveillance cul- tures sampled after 48 hours of admittance $(n=8)$, and those with missing surveillance culture samples $(n=6)$ were excluded and the remaining 45 subjects were included in the study group. Patient information including age, sex, comorbidities, time from injury to admission, history of previous hospitalizations, operations and antibiotic use, duration of admission, department admitting the patient, history of intensive care unit requirements, site and characteristics of injury, including type of trauma, open fracture classification (Gustilo Anderson), presence of wound site infection or sepsis, results of biochemical analysis at admission, presence of external fixator, number of debridement or vacuum assisted closure (VAC) procedures performed, transfusion requirements, complications recorded during follow up, and the antibiogram results of the surveillance cultures (nasal, rectal and wound swabs, tracheal aspirates and urine and blood cultures) were collected from the electronic medical records (3). Two groups were formed depending on the time from injury to admission which was $\leq 15$ days for group 1 and $\geq 16$ days for group 2. The study was carried out in accordance with the regulations of the Helsinki Declaration and a written consent form was obtained from all patients.

As a routine practice of infection control, rectal and nasal swabs and urine culture samples were collected to detect resistant bacterial colonization. Additional samples collected included blood cultures from patients with fever, endotracheal aspiration fluid from intubated or tracheostomized patients, surface swabs or deep tissue cultures obtained during the operation of patients with open wound infections. Contact isolation precautions were enforced for all subjects for 48-72 hours until the culture results were available. Contact isolation was extended throughout the hospitalization period for those whose cultures revealed resistant bacteria growth. Proper antibiotic therapy was initiated according to the suggestions of the infectious diseases consultant as soon as the culture results were available.

Nasal, perirectal and wound surface swabs were obtained using a cotton tipped swab and transport medium (Firat Med., Turkey) and sent to the microbiology laboratory. All microbiology samples were inoculated in blood agar, Mac Conkey agar and chocolate agar media, rectal swabs were additionally inoculated in D-Coccosel agar (bioMérieux Marcy l'Etoile, France) in order to isolate vancomycin resistant enterococci and incubated for $24-48$ hours at $37^{\circ} \mathrm{C}$. 
BacT/Alert ${ }^{\circledR}$ 3D system (bioMérieux, Marcy l'Etoile, France) was used to inoculate the blood culture samples. Samples from the positive blood culture vials were used to inoculate blood agar, MacConkey agar and chocolate agar media. The media were incubated at $37^{\circ} \mathrm{C}$ for 48 hours and isolated microorganisms were identified using VITEK ${ }^{\circledR} 2$ (bioMérieux, Marcy l'Etoile, France) automated system in addition to conventional methods. Antibiotic sensitivity was evaluated with the same automated system and Kirby-Bauer disc diffusion susceptibility test, according to the Clinical and Laboratory Standards Institute (CLSI) guidelines $(4,5)$.

Microorganisms were defined as multi-drug resistant (MDR) if resistant (non-susceptible) to at least one agent in three or more antimicrobial categories, extensively drug resistant (XDR) if susceptible to one or two antimi-
USA) software (3). Numeric variables were summarized as mean, standard deviation, minimum and maximum values and categorical variables were summarized according to frequency and percentage in the descriptive analysis.

\section{RESULTS}

A total of 45 patients, 44 (97.8\%) male, with a mean age of $30.7 \pm 12.9$ (range: $12-67$ ) years were included in the study. Twenty four (53.3\%) patients were hospitalized within 15 days from the time of injury (group 1) and 21 (46.6\%) were hospitalized after 15 days (group 2). Mean duration of hospitalization was 32 (range: $2-117$ ) days. Three (6.7\%) patients had coexisting diabetes mellitus (DM). Demographic characteristics, biochemistry results and injury characteristics of the patients are summarized in Tables 1,2 and 3.

Table 1: Characteristics of the patient group at admission-1

\begin{tabular}{lccc}
\hline & Overall & Group 1 ( $\mathbf{1 5}$ days) & Group 2 ( $\leq 16$ days) \\
\hline Male/female & $44 / 1$ & $24 /-$ & $20 / 1$ \\
Age, years (mean $\pm \mathrm{SD}$ ) (min-max) & $30.7 \pm 12.9(12-67)$ & $30.0 \pm 13.9(12-67)$ & $31.4 \pm 12.0(19-67)$ \\
Duration of hospitalization, days (mean $\pm \mathrm{SD})$ & $32 \pm 32.4(2-117)$ & $35.4 \pm 33.4(2-117)$ & $28.1 \pm 31.8(2-102)$ \\
& $\begin{array}{c}\text { Orthopedics: } 38(84.4 \%) \\
\text { Other } 7(15.6 \%)\end{array}$ & 18 & 20 \\
Admitting department & $\begin{array}{l}\text { (general surgery, neuro- } \\
\text { surgery, plastic surgery) }\end{array}$ & & \\
ICU requirement & $7(15.6 \%)$ & 6 & 1 \\
Sepsis at admission & $4(8.9 \%)$ & 3 & 1 \\
Operation prior to admission & $41(91.1 \%)$ & 22 & 19 \\
Complications & $9(20 \%)$ & 5 & 4 \\
Comorbidity & $3(6.7 \%)$ & 1 & 2 \\
\hline
\end{tabular}

crobial categories but resistant to at least one agent in all other categories, and pandrug resistant (PDR) if resistant to all agents in all antimicrobial categories, according to definitions for standardized international terminology document (6). All MRSA isolates were classified as MDR according to the same document (6).

Data on demographic characteristics of the patients, including age and sex, existing comorbidities, biochemical and microbiological test and culture results, duration of hospitalization, department the patient was hospitalized in intensive care unit requirements, occurrence of complications, VAC requirements, number of debridements, existence of co-pathogens in the wound, level of resistance of the microorganisms, presence of external fixators, blood transfusion requirements, means of injury, site of injury and open fracture classification (Gustilo Anderson) were analysed with SPSS (Statistical Package for Social Sciences) for Windows 11.0 (SPPS Inc., Chicago, IL,
Table 2: Characteristics of the patient group at admission-2

\begin{tabular}{lc}
\hline Parameters & Mean \pm SD \\
\hline White-cell count & $9066.4 \pm 3837.6$ \\
(3980-10004)/mm ${ }^{3}$ & $11.5 \pm 2.7$ \\
Hemoglobin (11.7-17.2) mg/dL & $35.2 \pm 7.9$ \\
Hematocrit (34.1-44.9) & $272622.2 \pm 148949.3$ \\
Platelet count & $85.1 \pm 116.9$ \\
(182000-369000)/mm & $49.9 \pm 38.8$ \\
CRP (0-5) $\mathrm{mg} / \mathrm{L}$ & $40.7 \pm 39.3$ \\
ESR (0-20) $\mathrm{mm} / \mathrm{hour}$ & $45.1 \pm 50.8$ \\
AST (0-32) U/L & $15.3 \pm 10.7$ \\
ALT (0-33)/L & $0.8 \pm 1.1$ \\
BUN & \\
Creatinine $(0.5-0.9) ~ \mathrm{mg} / \mathrm{dL}$ &
\end{tabular}


Table 3: Characteristics of the injuries

\begin{tabular}{|c|c|c|c|}
\hline & Overall & $\begin{array}{l}\text { Group } 1 \\
\text { ( } \leq 15 \text { days) }\end{array}$ & $\begin{array}{c}\text { Group } 2 \\
\text { ( } \geq 16 \text { days) }\end{array}$ \\
\hline \multicolumn{4}{|l|}{ Injury due to } \\
\hline Firearms & 30 (66.7\%) & 11 & 19 \\
\hline Bomb & 9 (20\%) & 9 & 0 \\
\hline Shrapnel & $5(11.1 \%)$ & 3 & 2 \\
\hline $\begin{array}{l}\text { Rocket } \\
\text { propellant }\end{array}$ & $1(2.52 \%)$ & 1 & 0 \\
\hline \multicolumn{4}{|l|}{ Site of injury } \\
\hline $\begin{array}{l}\text { Lower } \\
\text { extremity }\end{array}$ & 22 (48.9\%) & 11 & 11 \\
\hline $\begin{array}{l}\text { Upper } \\
\text { extremity }\end{array}$ & $11(24.4 \%)$ & 4 & 7 \\
\hline $\begin{array}{l}\text { Lower and } \\
\text { upper extremity }\end{array}$ & 1 (2.2\%) & 0 & 1 \\
\hline Non-extremity & $3(6.7 \%)$ & 2 & 1 \\
\hline Multiple injury & $8(17.8 \%)$ & 7 & 1 \\
\hline $\begin{array}{l}\text { External fixator at } \\
\text { admission }(+)\end{array}$ & $16(35.5 \%)$ & 10 & 6 \\
\hline VAC use & 17 (37.8\%) & 9 & 8 \\
\hline $\begin{array}{l}\text { Transfusion } \\
\text { requirement }\end{array}$ & 13 (28.9\%) & 8 & 5 \\
\hline
\end{tabular}

Prior to admission, 41 (91.1\%) of the patients had had an operation at a healthcare facility in Libya and all patients had had prophylactic antibiotic therapy. The majority of the injuries were due to firearms (66.7\%) and 22 (48.9\%) patients were injured on the lower extremities. Open bone fractures were present in 30 (66.6\%) patients, the most common form of which was Type III B (24.4\%), followed by Type III A (15.6\%), Type III C (11.1\%), Type II (8.9\%), and Type I (6.7\%) (3). The remaining 15 patients had closed fractures, unclassified non-extremity fractures and soft tissue injuries. Primary wound site infection was present in 28 (62.2\%) patients, and bacterial growth was detected in 23 of the wound cultures from these 28 patients, with 20 of the isolated agents being classified as XDR/MDR. Debridement of the wound tissue was performed on 43 patients, 17 of whom also received VAC. The median number of debridements performed was 1 (interquartile range: 1-44). Thirty eight patients were admitted to the orthopedics clinic, the remaining 7 patients had multiple traumas and were admitted to general surgery, neurosurgery, plastic surgery and ear nose throat clinics. Seven (15.5\%) of the patients had to be transferred to the intensive care unit, 6 of whom were acute phase (group 1) patients. The only difference between the characteristics of group 1 and 2 was that of the intensive care unit requirements ( $p>0.05)$.
The surveillance cultures inoculated in the first 48 hours of hospitalization revealed 40 microorganisms from the samples of 29 patients, which were gram-negative rods in 22 patients (55\%), gram-positive cocci in 17 patients (42.5\%) and fungus in 1 (2.5\%) patient (Figure 1). Of the 40 isolated microorganisms, 13 (32.5\%) were non-resistant, 10 (22.2\%) were MDR, and 13 (28.9\%) were XDR. Additionally, isolated Candida albicans strain was resistant to fluconazole and all coagulase negative staphylococci $(n=3)$ were methicillin resistant. None of the isolated bacteria were classified as PDR. Wound swab cultures revealed 30 (75\%) microorganisms, 19 (63.3\%) of which were gram-negative bacilli and of this 19,8 were Acinetobacter baumannnii classified as MDR or XDR (Figure 1). Rectal swab cultures did not reveal any vancomycin resistant enterococci. Distribution of the gram-negative bacilli obtained from the cultures is summarized in Figure 2. Resistance profiles showed that $91.6 \%$ of the non-fermentative gram-negative bacilli and $70 \%$ of enterobacteriaceae were either MDR or XDR.

Due to resistant infections, 8 patients received intravenous colistin which was combined with beta-lactam antibiotics in seven of these patients. The remaining one patient who received colistin combined with aminoglycoside and cefoperazone-sulbactam developed acute kidney failure but did not require renal replacement therapy after the antibiotics were stopped. Renal functions resumed to normal after one week and antibiotherapy was continued with dose adjusted colistin and cefoperazone-sulbactam combination.

Major complications were observed in $8(17.7 \%)$ patients in the study group. One patient developed acute renal failure after receiving intravenous cefoperazone-sulbactam, colistin and amikacin combination, but this was resolved following the termination of the combination therapy. Another patient developed toxic hepatitis presumed to be associated with carbapenem and non-steroid anti-inflammatory drug use. A Type III C fracture patient had a lower extremity amputation due to intractable wound site sepsis. Secondary wound site infections were detected in 4 patients, one patient had a urinary tract infection associated with urinary catheterization and one patient developed left hemiplegia due to intracranial injury. None of the patients died in the study group. Blood transfusions were performed in $13(28.9 \%)$ patients and no patient in the study group received massive transfusion. Duration of hospitalization was longer than 30 days in 18 patients and 11 of these patients were associated with resistant bacteria colonizations and $87.5 \%$ of all complications were observed in 7 of these long term patients. Fifteen (83.3\%) of these patients had Type III fractures. Of the 28 patients with primary site infections, 20 (71.4\%) also had Type III fractures. 


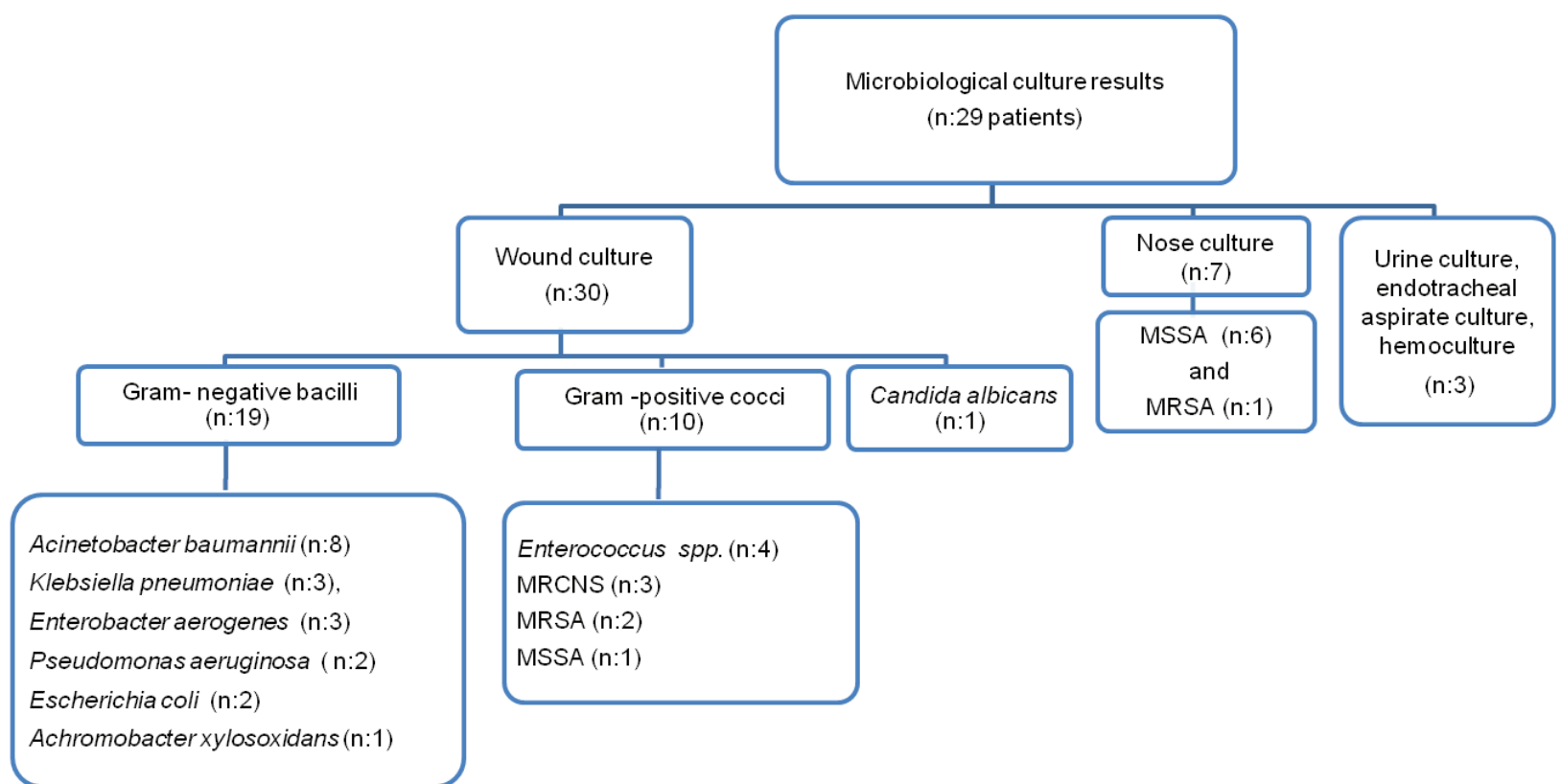

Figure 1: Distribution of microbiological culture results.

MSSA: Meticilline sensitive Staphylococcus aureus; MRSA: Meticilline resistant Staphylococcus aureus; MRCNS: Meticilline resistant coagulase negative Staphylococcus

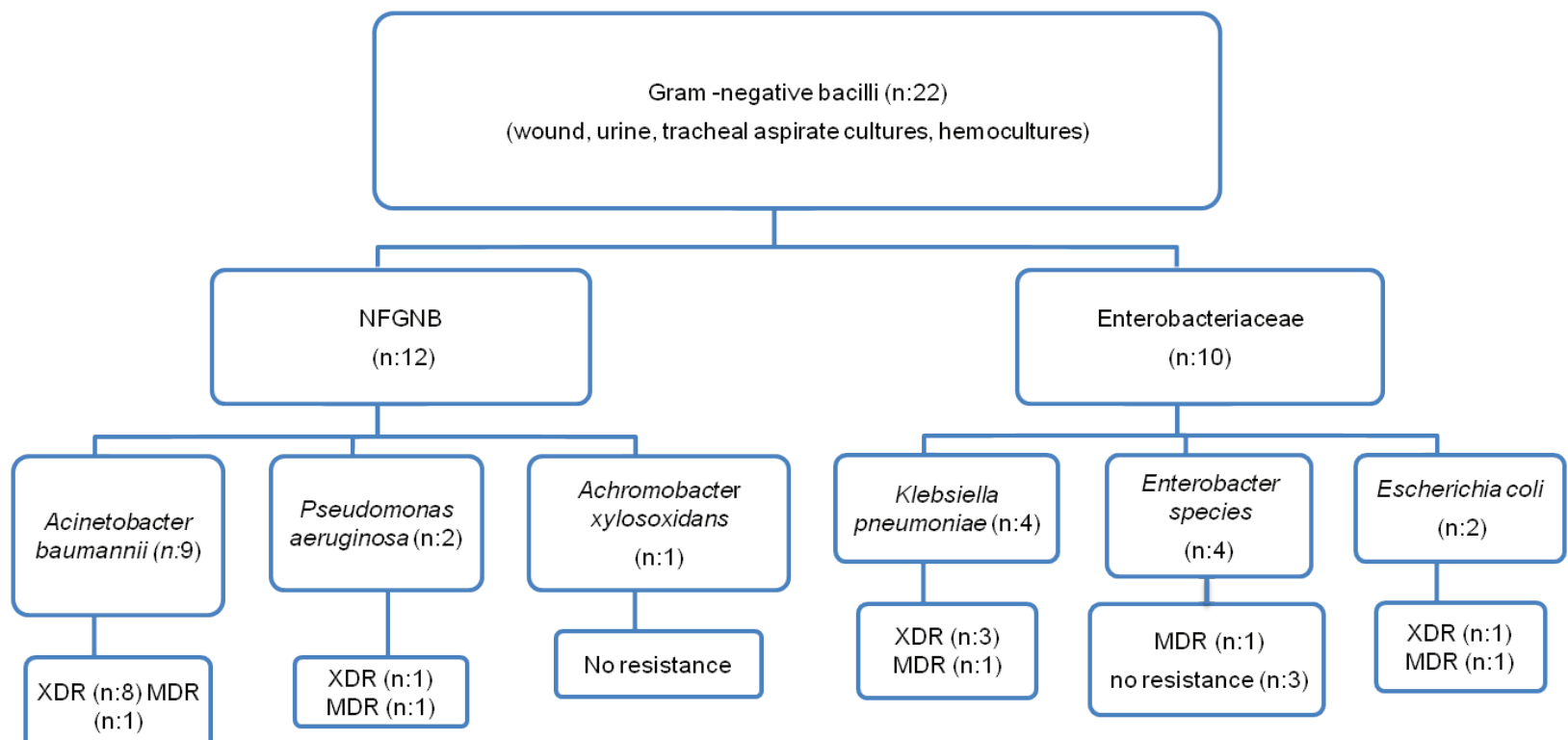

Figure 2: Distribution of gram-negative bacilli.

NFGNB: Nonfermenting gram-negative bacilli; XDR: Extensively drug-resistant; MDR: Multidrug-resistant

\section{DISCUSSION}

Warfare is a great tragedy that leaves enduring scars on communities both socially and economically. Most of the current conflicts worldwide are considered as fourth generation warfare, where the battleground is expanded to include civilian settlements, and the beginning and the ending of the conflict are more blurred, similar to conflicts where formally organized armies are replaced by civilians. Such conflicts, as the case in Libya which started out as a nonviolent protest and escalated into a civil war, exert widespread effects on the community, including hampering of healthcare facilities and an increase in CRI (7). 
CRI most commonly affects young, healthy males. Our study group consisted of mostly male (\%97.8), young individuals (median age 27 years), consistent with the previous reports $(7,8)$. Other parameters similar with the literature were the frequency of firearm injuries $(66.7 \%)$ and extremity wounds $(75.5 \%)$ in our study group $(7,9)$. The majority of the primary wound infection cases $(71.4 \%)$ had Type III fractures, which was also consistent with previous reports. Wound sepsis and amputation rates in Type III C fractures are reported as $42 \%$ and $42 \%(3,10)$. There was one Type III C fracture case in our group with an XDR Acetinobacter infection of the wound who developed sepsis and had to undergo lower extremity amputation.

Guidelines recommend that narrow spectrum antibiotics like ceftriaxone should be started within the first 24 hours in CRI (11). It has been reported that empirical use of broad spectrum antibiotics may lead to resistant bacterial overgrowth and possible emergence of resistant flora due to the treatment of these resistant strains, resulting in a potential source of nosocomial infections (12). Gradual increase of imipenem resistance over a period of years has been reported in 142 Acetinobacter strains isolated from CRI cases from Iraq and Afghanistan, which has been associated with empirical use of imipenem in these cases and resulted in the medical center's decision to stop the prophylactic use of carbapenems (13). Another report on $36 \mathrm{CRI}$ cases from Libya suggested that resistance to extended spectrum beta-lactamases (ESBL) observed in all the gram-negative strains isolated may be associated with the empirical use of wide spectrum antibiotics in this patient group, $90 \%$ of which received ceftriaxone and/or gentamicin, metronidazole and ciprofloxacin prophylactically for at least 5 days (14). Although it was not possible to obtain the complete medical records of all patients prior to their arrival, ceftriaxone, quinolone and/or metronidazole use was confirmed for 7 patients. A high frequency of wound site infection at arrival (62.2\%) (28/45 patients) and a 71.8\% (20/30 microorganisms) incidence of resistant bacteria, especially $A$. baumannnii $(26.6 \%)$, isolated from the cultures of these patients may be associated with nosocomial contamination and the use of wide spectrum antibiotics.

The third most common cause of mortality in CRI victims surviving the first 24 hours is sepsis. Wound site infection due to resistant gram-negative bacteria may be fatal (11). Although the measures to prevent wound site infection in CRI have not been thoroughly defined yet, a number of practices including proper and timely administration of antibiotics, early wound irrigation and surgical debridement, bone stabilization and delayed closure have been widely accepted as the basic principles in this patient group. In addition to removal of the necrotic tissue with aggressive debridement, initiation of VAC is also recommended, wherever possible (11). VAC accelerates wound healing by helping to reduce the requirement for dressings, decrease the localized edema, promote the granulation tissue formation and increase the wound drainage in addition to forming a barrier between the wound and the surrounding environment to prevent further contamination (15-17). The advantages of VAC are emphasized and recommended especially for CRI cases with extensive tissue damage $(11,17)$. In our study group, 43 patients had surgical debridements between 1 and 44 times and 17 of these patients also received VAC treatment.

The number of reports on resistant bacteria in CRI wound infections is increasing. Most common agents causing nosocomial wound site infection are $P$. aeruginosa, A. baumannii, Enterobacteriaceae, Staphylococcus aureus, enterococci and yeasts. A. baumannii appears to be an especially important pathogen in this group which commonly affects the skin and soft tissue and strains of this are increasingly reported as MDR in CRI wound infections (18). The difficulty of treating Acinetobacter infections is due not only to the extensive antibiotic resistance, but also to the biofilm production of the bacteria (19-21). Moran et al reported that among the 125 isolates obtained from various samples of $871 \mathrm{CRI}$ victims treated in Iraq, the frequency of MDR strains was higher among $A$. baumannii compared to other gram-negative bacteria $(80 \%$ and $17-29 \%$, respectively) (22). Koole et al. reported that resistant bacteria were isolated from the samples of $59 \%$ of the $51 \mathrm{CRI}$ victims treated in Holland and ESBL producing enterobacteriaceae was detected in $51 \%$ of the study group (23).

Seventy five percent of the microorganisms isolated from the study group were obtained from the wound samples and $63.3 \%$ of them were gram-negative rods. Similar to the previous reports, the majority of these isolates were A. baumannii, $42.4 \%$ of which were MDR or XDR, and carbapenemase producing $A$. baumannii and Klebsiella pneumoniae isolate rates were $88 \%$ and $75 \%$, respectively. A study from a single center in Libya which was published in 2015 reported that of the 94 gram-negative isolates that were examined, $96 \%$ of $A$. baumannii and $94 \%$ of $K$. pneumoniae strains were carbapenemase producing (24). Another study from Libya which was carried out by Buzaid et al in a trauma center showed that $31 \%$ of the 200 S. aureus isolates obtained from different samples were found to be methicillin resistant (25). Methicillin resistance rate among $10 \mathrm{~S}$. aureus strains isolated from nose and wound samples in our study group was similarly $30 \%$.

Colistin is a reasonable alternative in the treatment of multi-resistant gram-negative bacterial wound infections. After its introduction in 1960s, intravenous form of colistin was widely abandoned in the 1980s, except for the treatment of cystic fibrosis patients, due to high risk of nephrotoxicity. But currently, it has been resurrected as a 
valid treatment option for the rapidly emerging multi-resistant bacteria in the absence of novel wide spectrum antibiotics. Nephrotoxicity and neurotoxicity are the two main factors limiting the use of colistin. Nephrotoxicity of colistin is dose dependent and rarely permanent (26). The frequency of nephrotoxicity (necessitating termination of treatment) among $66 \mathrm{CRI}$ victims treated with colistin is reported to be $21 \%$ (27). Eight young patients with no comorbidity or underlying renal disease received IV colistin for a mean duration of 32 days in our study group and treatment was terminated in only $1(12.5 \%)$ patient due to reversible kidney injury.

In conclusion, despite the limited number of cases, this study presents the characteristics of the Libyan combat victims treated by a multidisciplinary team in a single center. In this report we shared our experience on a limited number of CRI victims treated in a single center by a multidisciplinary team. Surveillance cultures showed that the patients were infected with multi resistant gram-negative bacteria including A. baumannii, P. aeruginosa, K. pneumoniae and Escherichia coli. The relatively younger age of the study group and the absence of serious comorbidities made it possible to administer high doses and long term antibiotherapy. Frequent application of wound debridement, use of VAC therapy and timely closure of the wounds are also considered to be important factors in minimizing mortality. Isolation of MDR and XDR strains of $A$. baumannii and $P$. aeruginosa from wound cultures of consecutive patients suggests that empirical therapy with narrow spectrum antibiotics is not sufficient in this patient group. This experience urged us to consider earlier initiation of extended spectrum antibiotherapy in CRI patients. Surveillance cultures and contact isolation helped in limiting nosocomial contamination. In conclusion, CRI injuries require a rapid, patient and multidisciplinary approach. Early surgical wound debridement, early initiation of antibiotic therapy in the proper dose and spectrum, and obtaining wound site cultures whenever necessary may help to provide favorable outcomes in CRI victims.

Acknowledgements: We would like to thank Prof. Dr. Didem Dal and Prof. Dr. Simru Tuğrul for their help and support during the treatment of the patients.

Etik Komite Onayı: Bu çalışma için etik komite onayı alınmıştır.

Bilgilendirilmiş Onam: Katılımcılardan bilgilendirilmiş onam alınmıştır.

Hakem Değerlendirmesi: Dış bağımsız.

Yazar Katkıları: Çalışma Konsepti/Tasarım- Z.Ç.K., B.P.Ş.; Veri Toplama- Z.Ç.K., T.B., A.B.; Veri Analizi/Yorumlama- Z.Ç.K., B.P.Ş.; Yazı Taslağı- Z.Ç.K., T.B., A.B.; İçeriğin Eleştirel İncelemesiB.P.Ş.; Son Onay ve Sorumluluk- Z.Ç.K., T.B., A.B., B.P.Ş.; Süpervizyon- Z.Ç.K.
Çıkar Çatışması: Yazarlar çıkar çatışması beyan etmemişlerdir.

Finansal Destek: Yazarlar finansal destek beyan etmemişlerdir.

Teşekkür: Prof. Dr. Didem Dal ve Prof. Dr. Simru Tuğrul'a hastaların tedavisi sırasında yardım ve destekleri için teşekkür ediyoruz

Ethics Committee Approval: Ethics committee approval was received for this study.

Informed Consent: Written consent was obtained from the participants.

Peer Review: Externally peer-reviewed.

Author Contributions: Conception/Design of Study- Z.Ç.K., B.P.S.;; Data Acquisition- Z.Ç.K., T.B., A.B.; Data Analysis/Interpretation- Z.Ç.K., B.P.Ş.; Drafting Manuscript- Z.Ç.K., T.B., A.B.; Critical Revision of Manuscript-B.P.Ş.; Final Approval and Accountability- Z.Ç.K., T.B., A.B., B.P.Ş.; Supervision- Z.Ç.K.

Conflict of Interest: Authors declared no conflict of interest.

Financial Disclosure: Authors declared no financial support.

\section{REFERENCES}

1. Murray CK, Obremskey WT, Hsu JR, Andersen RC, Calhoun $\mathrm{JH}$, Clasper JC, et al. Prevention of infections associated with combat-related extremity injuries. J Trauma 2011;71(2 suppl 2):S235-57. [CrossRef]

2. Merrens A, Rapp C, Delaune D, Danis J, Berger F, Michel R. Prevention of combat-related infections: Antimicrobial therapy in battlefield and barrier measures in French military medical treatment facilities. Travel Med Infect Dis 2014;12(4):318-29. [CrossRef]

3. Gustilo RB, Mendoza RM, Williams DN. Problems in the management of type III (severe) open fractures: a new classification of type III open fractures. J Trauma 1984;24(8):742-6. [CrossRef]

4. Hudzicki J. Kirby-Bauer Disk Diffusion Susceptibility Test Protocol. Am Soc Microbiol 2013;(December 2009):1-23.

5. The Clinical and Laboratory Standards Institute. Performance Standards for Antimicrobial Susceptibility Testing CLSI Supplement M 100S;2016.

6. Magiorakos AP, Srinivasan A, Carey RB, Carmeli Y, Falagas $M E$, Giske CG, et al. Multidrug-resistant, extensively drugresistant and pandrug-resistant bacteria: An international expert proposal for interim standard definitions for acquired resistance. Clin Microbiol Infect 2012;18(3):268-81. [CrossRef]

7. Bodalal Z, Mansor S. Gunshot injuries in BenghaziLibya in 2011: The Libyan conflict and beyond. Surgeon 2013;11(5):258-63. [CrossRef]

8. Aras M, Altaş M, Yilmaz A, Serarslan Y, Yilmaz N, Yengil E, et al. Being a neighbor to Syria: A retrospective analysis of patients brought to our clinic for cranial gunshot wounds in the Syrian civil war. Clin Neurol Neurosurg 2014;125:222-8. [CrossRef]

9. Geiger S, McCormick F, Chou R, Wandel AG. War wounds: Lessons learned from operation iraqi freedom. Plast Reconstr Surg 2008;122(1):146-53. [CrossRef] 
10. Kumar G, Narayan B. Prevention of infection in the treatment of one thousand and twenty-five open fractures of long bones. retrospective and prospective analyses. Class Pap Orthop 2014:527-30. [CrossRef]

11. Hospenthal DR, Murray CK, Andersen RC, Bell RB, Calhoun $\mathrm{JH}$, Cancio LC, et al. Guidelines for the prevention of infections associated with combat-related injuries: 2011 Update. J Trauma 2011;71:S210-34. [CrossRef]

12. Calhoun JH, Murray CK, Manring MM. Multidrug-resistant organisms in military wounds from Iraq and Afghanistan. Clin Orthop Relat Res 2008;466(6):1356-62. [CrossRef]

13. Hawley JS, Murray CK, Griffith ME, McElmeel ML, Fulcher LC, et al. Susceptibility of Acinetobacter strains isolated from deployed U.S. military personnel. Antimicrob Agents Chemother 2007;51(1):376-8. [CrossRef]

14. Franka EA, Shembesh MK, Zaied AA, El-Turki E, Zorgani A, Elahmer OR, et al. Multidrug resistant bacteria in wounds of combatants of the Libyan uprising. J Infect 2012;65(3):27981. [CrossRef]

15. Pollak AN. Use of negative pressure wound therapy with reticulated open cell foam for lower extremity trauma. J Orthop Trauma 2008;22(10):S142-5. [CrossRef]

16. Powell ET. The role of negative pressure wound therapy with reticulated open cell foam in the treatment of war wounds. J Orthop Trauma 2008;22(10):S138-S141. [CrossRef]

17. Leininger $B E$, Rasmussen $T E$, Smith $D L$, Jenkins $D H$, Coppola C. Experience with wound VAC and delayed primary closure of contaminated soft tissue injuries in Iraq. J Trauma 2006;61(5):1207-11. [CrossRef]

18. Sebeny PJ, Riddle MS, Petersen K. Acinetobacter baumannii skin and soft-tissue infection associated with war trauma. Clin Infect Dis 2008;47(4):444-9. [CrossRef]
19. Dallo SF, Weitao T. Insights into Acinetobacter war-wound infections, biofilms, and control. Adv Skin Wound Care 2010;23(4):169-74. [CrossRef]

20. Gaddy JA, Actis LA. Regulation of Acinetobacter baumannii biofilm formation Jennifer. Futur Microbiol 2009;4:273-8. [CrossRef]

21. Deveci Ö, Dal T, Tekin R, Bozkurt F, Tekin A, Dayan S. Carbapenem resistance in Acinetobacter baumannii: where is it heading? Infez Med 2013;21(3):211-5.

22. Moran KA, Murray CK, Anderson EL. Bacteriology of blood, wound, and sputum cultures from non-US casualties treated in a combat support hospital in Iraq. Infect Control Hosp Epidemiol 2008;29(10):981-4. [CrossRef]

23. Koole K, Ellerbroek PM, Lagendijk R, Leenen LPH, Ekkelenkamp MB. Colonization of Libyan civil war casualties with multidrug-resistant bacteria. Clin Microbiol Infect 2013;19(7):E285-7. [CrossRef]

24. Elramalli A, Almshawt N, Ahmed MO. Current problematic and emergence of carbapenemase-producing bacteria: A brief report from a libyan hospital. Pan Afr Med J 2017; 26:180. [CrossRef]

25. Buzaid N, Elzouki AN, Taher I, Ghenghesh KS. Methicillinresistant Staphylococcus aureus (MRSA) in a tertiary surgical and trauma hospital in Benghazi, Libya. J Infect Dev Ctries 2011;5(10):723-6. [CrossRef]

26. Ordooei Javan A, Shokouhi S, Sahraei Z. A review on colistin nephrotoxicity. Eur J Clin Pharmacol 2015;71(7):80110. [CrossRef]

27. Hartzell JD, Neff R, Ake J, Howard R, Olson S, Paolino $K$, et al. Nephrotoxicity Associated with Intravenous Colistin (Colistimethate Sodium) Treatment at a Tertiary Care Medical Center. Clin Infect Dis 2009;48(12):1724-8. [CrossRef] 